\title{
The Role of Competitors and Customers in the Development of Environmentally Sound Technologies
}

\section{Magdalena Marczewska*}

\begin{abstract}
The article presents two important forces influencing the development of product innovations by suppliers of environmentally sound technologies, namely competitors and consumers. It discusses these phenomena on the basis of different theoretical approaches (Ansoff and Stewart, 1967; Von Hippel, 1987, 2005, 2007; Prahalad and Ramaswamy, 2004). The results of the study show that Polish companies-suppliers of environmentally sound technologies are willing to gain inspiration from both demand and supply side market players. In case of supply side of the market, in most cases inspiration was not aimed at copying existing successful ideas. The competitors are perceived rather as a source of inspiration for further development of technological solutions. Although companies concentrate on having a relationship with customers and track their behavior, these relations have not been established by the Polish companies researched here in order to treat users as co-creators of product improvements or novelties.
\end{abstract}

Keywords: environmentally sound technologies, customers, competitors, product innovations, user-driven innovations.

\section{INTRODUCTION}

In times of increasing competition and continuously changing customer needs, efficient response to environmental changes has become an important success factor for enterprises (Homburg, Grozdanovic and Klarmann, 2007, p. 18). In order to survive and thrive on such a competitive market, a company must seek to respond continuously to opportunities and threats posed by a dynamic environment (White, Varadarajan and Dacin, 2003, p. 63). Over the years, there has been a visible shift in the role of the consumer, from unaware to informed, from isolated to connected, from passive to active (Prahalad and Ramaswamy, 2004, p. 2). Empirical research has revealed that in many fields, users are more likely to contribute to the inquiring marketing researcher than

\footnotetext{
* Magdalena Marczewska, M.A., Faculty of Management, University of Warsaw, 1/3 Szturmowa Street, 02-678 Warsaw,
} Poland, mmarczewska@wz.uw.edu.pl. 
research gathering data concerning their unmet needs. Moreover, they can prompt insights and new ideas regarding solutions that might better respond to their needs (Urban and Von Hippel, 1988, p. 569). Environmental markets represent a wide range of relationships between companies that collaborate and compete on this market. This system of forces is crucial for the innovative process and new products development (Skea, 1995, pp. 402-405).

The main purpose of this study is to identify and analyze two important factors influencing the development of product innovations by suppliers of environmentally sound technologies, namely competitors and consumers. The study examines an impact of competitors and consumers on the product portfolio of companies-suppliers of environmental technologies, including their decisions to develop new solutions, withdraw or improve originally created ones. Moreover, the importance of consumers and competitors as a source of inspiration for innovation will be identified. The research questions are the following:

To what extent has the imitation of competitors' ideas resulted in creating and developing successful product innovations by the companies-suppliers of environmentally sound technologies in Poland?

How do companies gather information about specific technologies offered by their competitors?

What is the role of customers in the development of environmentally sound technologies offered by the companies?

The paper seeks to show the influence of competitors and customers on companies' decisions on developing environmentally friendly product innovations and analyze this phenomena from management of technology and innovation management perspectives.

\section{LITERATURE REVIEW}

The issues of sustainable development and the relationships between the environment and economy are increasingly arising as the topics of discussions amongst the society, policy makers, researchers and businesses. Recent innovation studies concerned with the environmental issues are interested in capturing environmentally friendly changes in technology and the examining behavior of market players, such as companies, their competitors and customers. A previous generation of the research on environmental innovation was primarily focused on the generations of technologies and their diffusion (Weber and Hemmelskamp, 2005, pp. 58-59). However, this approach does not seem to be sufficient nowadays as it fails to adequately capture the relevant market forces. Therefore, this study goes in line with current research strands focusing on the role of two groups of market players,

Perspectives on Innovations Management - Environmental, Social and Public Sector Innovations, Krzysztof Klincewicz, Anna Ujwary-Gil (Eds.) 
such as competitors and consumers in innovation activity of the suppliers of environmentally sound technologies. Before going further with this analysis it is necessary to define environmentally sound technologies. These are "techniques and technologies capable of reducing environmental damage through processes and materials that generate fewer potentially damaging substances, recover such substances from emissions prior to discharge, or utilize and recycle production residues" (United Nations, 1997, p. 30). During the evaluation of such technologies, the interaction with socio-economic and cultural terms and conditions in which they are implemented should be taken into account (United Nations, 1997, p. 30). There are many studies that concentrate on classifying the environmentally sound technologies (Skea, 1995, pp. 389-393), their adoption (Luken and Van Rompaey, 2008), policy design and implementation (Taylor, Rubin and Hounshell, 2005; Jaffe, Newell and Stavins, 2004), technology transfer (Perez Pugatch, 2011; Tébar Less and McMillan, 2005; Juma, 1994), assessment (International Environmental Technology Centre, 2003), and intellectual property rights frameworks (Ebinger and Avasarala, 2009). Although all these topics are associated with the actions undertaken by the suppliers of environmental technologies, who design and launch environmentally friendly solutions, the process of the development of such products and services has not yet been widely examined.

Currently, there are two main tendencies that determine the activities of enterprises. On the one hand, it is striving to create new knowledge, innovations, new solutions because such actions are seen as opportunities for growth. On the other hand, there is a tendency to create a certain balance between the different types of activities for the sustainable development of the company (Azzone and Noci, 1996; Bansal and Roth, 2000). These two trends have influenced the companies' need to focus on both ecology and innovation in their business activity (Cleff and Rennings, 1999).

There are many factors that influence companies' behavior and willingness to introduce innovative products and technologies to the market. Among them, it is possible to distinguish two categories: internal factors, which origin from the company and external ones, coming from the organizational environment (Janasz and Kozioł, 2007, p. 20). The first group consists of a firm's R\&D activity and knowledge, skills and resources gathered inside the company (Janasz and Leśkiewicz, 1995; Białoń, 2010). The later one is composed of the influential forces of competitors, information derived from the market demand (Sosnowska, 2000) and knowledge sourced for research institutions (Penc, 1999, pp. 160-163).

Innovations created in response to identified market needs are named demand-pull innovations (Janasz and Kozioł, 2007). Their existence has 
been highlighted in the Rothwell's five generations of innovation framework (Rothwell, 1992). Another demand side approach to the new products creation is the concept of user-driven innovation. According to this concept the users are involved in developing new products, services and ideas (Von Hippel, 2005). It requires understanding the needs of users and their engagement in the process of enterprise development (TemaNord, 2006).

Customers play an important role in a company's development. A well established relationship with the customers and examining their motivation to buy and use firm's products and services is important for defining company's opportunities for growth (Johnson, Christensen and Kagermann, 2010, pp. 51-61). Clients play a key role in improving and developing new product or service ideas (Carrillo-Hermosilla, Del Río and Könnölä, 2009, pp. 17-19). In literature a special group of clients named "lead users" has been identified (Urban and Von Hippel, 1988 p. 569). They can be defined using two following characteristics:

- these clients have needs that will be common in a marketplace long time before other customers;

- they will highly benefit by obtaining a solution (product or service), which is in line with the needs they present.

According to Von Hippel $(1988,2005)$, in order to identify the right group of customers who can be involved in the idea generation and development of the products, the lead user methodology should be applied (identification of trends on which users have leading position, identification of lead users, development of lead user product idea, market testing in order to see if the idea fulfills the needs of typical users). Moreover, the research shows that customers often use the products in ways that they were previously not designed for. Knowing such things can help the company to find new ways to extend its product portfolio (Anthony, Eyring and Gibson, 2010, pp. 125-126). Although many large companies gather information and data about the people and enterprises that buy their goods, these efforts do not guarantee gaining a sufficient amount of knowledge (Zook, 2010, pp. 161-164). Zook (2010) conducted the research within the companies that care about monitoring their clients' activity and found out that only $25 \%$ of them declare that they fully understand their customers. According to the findings of "Management Tools \& Trends" survey, in 2013 Customer Relationship Management (CRM) is seen as an important investment priority (Rigby and Bilodeau, 2013). CRM was first introduced in the survey in 2000 and was ranked $15^{\text {th }}$ in terms of usage and $22^{\text {nd }}$ in terms of satisfaction out of 25 other tools. In 2013 it was ranked by the companies first in both usage and satisfaction. At the same time, CRM has moved from company-centric approach to the world of co-creating value with customers, where enterprises need to hold dialogues with their

Perspectives on Innovations Management - Environmental, Social and Public Sector Innovations, Krzysztof Klincewicz, Anna Ujwary-Gil (Eds.) 
clients, rather than simply target them (Prahalad and Ramaswamy, 2004, pp. 132-134). A successful company is able to create customer value proposition (CVP) (Johnson, Christensen and Kagermann, 2010, pp. 51-61). According to Bower and Christensen (2010), customers have extraordinary power in influencing enterprises paths of investment. It is important for the company to care about their preferences, especially while thinking about launching new product or developing innovative technology. In many firms, processes used to forecast technological trends, learn about customers' needs, allocate resources, asses profitability and commercialize new products are focused on current customers and markets in order to exclude the goods that do not meet clients' needs (Bower and Christensen, 2010, pp. 20-34). On the other hand, these companies focus on constant development of innovative technologies, both incremental and radical, in the direction of the future generations of customer's potential needs, but make the decision of commercialization only if their products meet the needs and requirements of mainstream customers (Bower and Christensen, 2010, pp. 20-34).

A review of empirical studies shows that there are customers who actively participate in the process of creating innovative solutions and become inventors or co-developers (Hienerth, Von Hippel and Baldwin, 2006, pp. 1291-1313). The evidence of such phenomenon are, among others, the cases of mountain bikes (Luthje, Herstatt, and Von Hippel, 2005, pp. 951-965), chemical production process (Freeman, 1968), CAD software (Urban and Von Hippel, 1988, pp. 569-582), innovations in oil refining (Enos, 2013), and scientific instruments (Riggs and Von Hippel, 1994, pp. 459-469). In addition, research reveals that users also play an important role in the development of consumer goods innovations (Franke and Shah, 2003, pp. 157-178). Users with similar needs form sometimes user-innovation communities, where they can cooperate and assist each other with their innovations development (e.g. open source communities in which information, assistance and innovative problem solutions are freely shared) (Foray, 2006, pp. 62-64). The output of such process can be called experience innovation (Prahalad and Ramaswamy, 2004, pp. 51-54).

The same mechanisms concerning enterprise-customer behavior practices apply to the companies that develop innovations, especially in the field of environmentally sound technologies (Carrillo-Hermosilla, Del Río and Könnölä, 2009, pp. 17-19). User-driven innovation can widely influence the extent and direction of products developed within the company or industry (Von Hippel, 2005).

Within the years, customers' relationship with the companies has changed, and along with it the tools that firms use to analyze and assess their behavior (see: Table 1). The recent research of Prahalad and Krishnan 

Technologies

(2010) has shown that in developing innovations companies should seek to co-create value with different types of customers, not only lead users. The authors state that such approach is helpful in the process of identifying and foreseeing evolution paths of all sorts of current and future customers (Prahalad and Krishnan, 2010, pp. 72-86).

Table 1. The evolution and transformation of the company-consumer interactions

\begin{tabular}{|c|c|c|c|c|}
\hline \multicolumn{4}{|c|}{ Consumers as Passive Audience } & \multirow{2}{*}{$\begin{array}{l}\text { Consumers as } \\
\text { Co-Creators } \\
\text { Beyond } 2000\end{array}$} \\
\hline Time Frame & $\begin{array}{l}\text { 1970s, } \\
\text { early 1980s }\end{array}$ & $\begin{array}{l}\text { Late } 1980 \mathrm{~s} \\
\text { and early 1990s }\end{array}$ & $1990 \mathrm{~s}$ & \\
\hline $\begin{array}{l}\text { Role of the } \\
\text { consumer and } \\
\text { concept of the } \\
\text { market }\end{array}$ & \multicolumn{3}{|c|}{$\begin{array}{l}\text { Consumers are "outside the firm"; they are seen as passive } \\
\text { buyers with a predetermined role of consumption. Consumers } \\
\text { are a target for exchanging the firm's offerings. }\end{array}$} & $\begin{array}{l}\text { Consumers are part of } \\
\text { the enhanced network } \\
\text { of competencies; they } \\
\text { co-create (and } \\
\text { co-extract) value. } \\
\text { They are collaborators, } \\
\text { co-developers, and } \\
\text { competitors. }\end{array}$ \\
\hline $\begin{array}{l}\text { Managerial view } \\
\text { of consumers }\end{array}$ & $\begin{array}{l}\text { The consumer } \\
\text { is an average } \\
\text { statistic; groups } \\
\text { of buyers are } \\
\text { predetermined } \\
\text { by company. }\end{array}$ & $\begin{array}{l}\text { The consumer is } \\
\text { an individual statistic } \\
\text { in a transaction, } \\
\text { anywhere from } \\
\text { a database record } \\
\text { to an individually } \\
\text { addressable entity. }\end{array}$ & $\begin{array}{l}\text { The consumer } \\
\text { is a person; } \\
\text { cultivate trust and } \\
\text { relationships. }\end{array}$ & $\begin{array}{l}\text { The consumer is not } \\
\text { only a person whose } \\
\text { individual identity must } \\
\text { be respected, but also } \\
\text { embedded in thematic } \\
\text { communities and part of } \\
\text { an emergent social and } \\
\text { cultural fabric. }\end{array}$ \\
\hline $\begin{array}{l}\text { Company's } \\
\text { interaction with } \\
\text { consumers and } \\
\text { development } \\
\text { of products and } \\
\text { services }\end{array}$ & $\begin{array}{l}\text { Traditional } \\
\text { market research } \\
\text { and inquiries. } \\
\text { Preconfigured } \\
\text { products and } \\
\text { services are } \\
\text { created without } \\
\text { much feedback. }\end{array}$ & $\begin{array}{l}\text { Shift from selling to } \\
\text { helping consumers } \\
\text { via help desks, call } \\
\text { centers, and } \\
\text { customer service. } \\
\text { Identify problems, } \\
\text { then redesign } \\
\text { products and services } \\
\text { based on feedback. }\end{array}$ & $\begin{array}{l}\text { Identify solutions } \\
\text { from lead users. } \\
\text { Customize } \\
\text { products and } \\
\text { services from } \\
\text { preconfigured } \\
\text { menu of features. }\end{array}$ & $\begin{array}{l}\text { Consumers are } \\
\text { co-creators of value. } \\
\text { Dialogue, access, } \\
\text { risk assessment, and } \\
\text { transparency are building } \\
\text { blocks of co-creation of } \\
\text { value. Companies and } \\
\text { lead consumer co-shape } \\
\text { expectations and market } \\
\text { acceptance of experience } \\
\text { environments. }\end{array}$ \\
\hline $\begin{array}{l}\text { Purpose } \\
\text { and flow of } \\
\text { communication }\end{array}$ & $\begin{array}{l}\text { Gaining access } \\
\text { to and targeting } \\
\text { predetermined } \\
\text { groups; one-way } \\
\text { communication. }\end{array}$ & $\begin{array}{l}\text { Database marketing; } \\
\text { firm-to-individual } \\
\text { access; two-way } \\
\text { communication. }\end{array}$ & $\begin{array}{l}\text { Relationship } \\
\text { marketing; } \\
\text { two-way } \\
\text { access and } \\
\text { communication. }\end{array}$ & $\begin{array}{l}\text { Active dialogue with } \\
\text { consumers to co-shape } \\
\text { individual expectations } \\
\text { and co-construct } \\
\text { personalized experiences. } \\
\text { Multiway access, network } \\
\text { communication. }\end{array}$ \\
\hline
\end{tabular}

Source: Prahalad and Ramaswamy (2004, pp. 214-215).

Perspectives on Innovations Management - Environmental, Social and Public Sector Innovations, Krzysztof Klincewicz, Anna Ujwary-Gil (Eds.) 
Another factor that can motivate company's managers to develop novelties, especially eco-innovations, is the good environmental performance of their competitors. Such action can be also undertaken in order to improve firm's reputation in the eyes of customers (Luken and Van Rompaey, 2008, p. 69). The behavior of company's competitors can be also impeding. The interest in the developing technology of powerful but less innovative market players can delay or hinder the innovation process (Visser, Jongen and Zwetsloot, 2008, pp. 85-94). In general, the existence of competitors can stimulate innovation. Enterprises may race to be first to the market with the innovative product of technology. Moreover, companies may come up with lower cost manufacturing and in this way, by increasing their profit, may reveal their ability to compete. In addition, competition can stimulate firms to identify and fulfill customers' yet undiscovered and unmet needs and develop new solutions to satisfy them (Federal Trade Commission, 2003). The presence of relevant competitors can also be a source of strategic advantages. These can be classified into four general categories: strengthening the competitive advantage, improving current structure of the industry, supporting market development and preventing new potential entries (Porter, 2006, pp. 254265).

Ansoff and Stewart (1967) claim that a systematic analysis of the market is needed in order to adequately manage the corporate technology. On the basis of the characteristics of parameters of technologically intensive businesses they have proposed a model of strategies that examines the timing of a firm's entry into an emerging industry (see: Figure 1). Within the model, the company may choose one of the possible approaches to the market and technological knowledge: first to the market, follow the leader, application engineering and me-too (Ansoff and Stewart, 1967, pp. 81-83). 


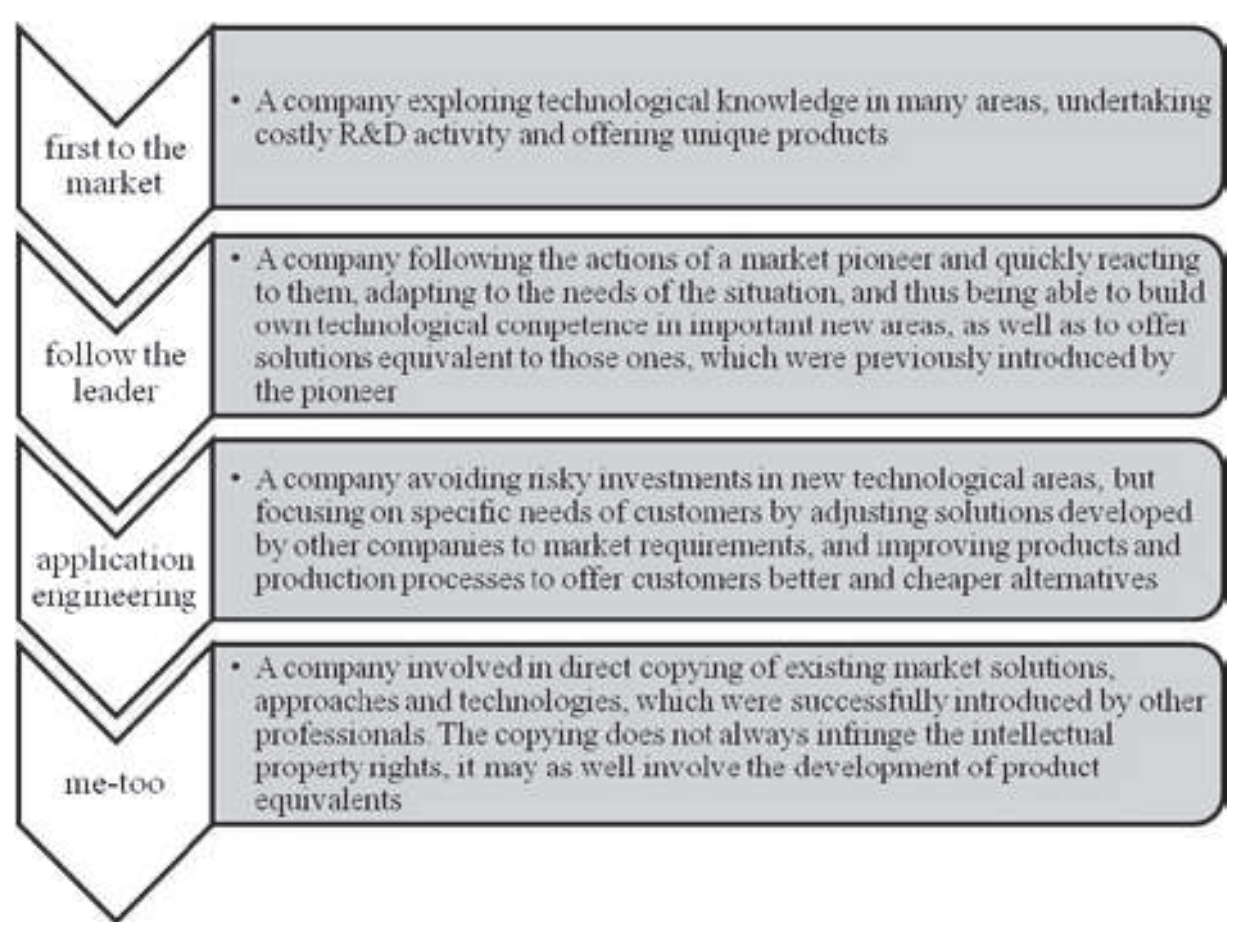

Figure 1. Possible approaches to the market and technological knowledge

Source: Own elaboration based on: Ansoff and Stewart (1967, pp. 81-83).

It is worth noting, that the commonly called "imitators" in the model of Ansoff and Stewart are represented by three types of strategies and should not be confused with the kind of companies that simply copy technologies without any own contribution. The concept of "creative imitations", which are developed by the companies who offer new applications of previously present technologies that address different user segments was also put forward by Peter Drucker (1992, pp. 235-240). This phenomenon is created by markets, rather than solutions or technologies, and by customers rather than technology suppliers. It can be defined as market-oriented and marketinspired approach. Creative imitators serve the market niche that is not fulfilled by pioneers, so they do not create the demand for products, they satisfy the existing one (Drucker, 1992, pp. 235-240).

The economic literature has long pointed to the existence of imitation, especially in terms of innovative activity of the pioneers (Schumpeter, 1939). In order to distinguish the types of market players Schumpeter describes the leader as the one who effectively directs the means of production into new areas of application (Schumpeter, 1960, pp. 117-150). Like other researchers, Michael Porter also distinguishes market leaders from followers. He claims, 
however, that appropriate actions that need to be undertaken to deal with competitors apply to both of these groups (Porter, 2006, p. 253).

The role of competition has been also discussed by Von Hippel (1987, 2005, 2007). He distinguishes the competition between two groups of market players: customers and rivals. He claims that there is a phenomenon named informal know-how trading, which is a routine and informal exchange of information between engineers and employees working in different enterprises. According to his findings, this type of behavior can be sometimes observed among even direct rivals (Von Hippel, 1988, pp. 76-90).

To sum up the literature review, it should be pointed out that the results of previous research suggest that both consumers and competitors can play an important role in the developing innovations, but their importance depends on company's strategy. Therefore, it is worth examining to what extent customers and competitors influence the development of product innovations by the companies-suppliers of environmentally sound technologies in Poland. The detailed analysis of the importance of this source of innovation for suppliers of environmentally sound technologies in Poland will be conducted in next sections of this article.

\section{RESEARCH METHODS}

The research focuses on analyzing the development of environmentally sound technologies in Poland with regard to the role of competitors and customers. The data was gathered by conducting in-depth, semi-structured interviews with the representatives of selected 40 companies operating in the field of environmentally sound technologies. The chosen enterprises represent six broad areas of environmental technology:

- renewable energy sources: manufacturers of solar collectors, briquetting machines, fuel cells, hydro power and biogas solutions (10 firms);

- waste management: suppliers of solutions for treatment of hazardous waste and by-products of coal combustion, secure storage of liquid fuels, biomass gasification, processing plastics into liquid fuels (9 firms);

- water and wastewater management: suppliers of water treatment plants, water treatment solutions and drying of sewage sludge solutions (7 firms);

- air protection: suppliers of pollution emission reduction systems (2 firms);

- energy efficiency: suppliers of technologies that support saving electricity and heat, solutions for passive houses, energy-efficient lighting solutions, heat pumps, media management systems for energy ( 9 firms); 
- biodiversity protection: suppliers of technologies for reclamation of lakes and barriers to protect fish (3 firms).

The companies distinguish themselves from other environmentally sound technologies industry market players in Poland as suppliers of own, eco-innovative products and their interest in international markets. The companies from the sample were examined by independent experts in terms of the originality and ecological significance of the innovative products and technologies they introduce to the market, as well as their environmental impact and potential for development. Interview with each company representative was based on the same script, which contained a list of detailed questions. The interviewers were allowed to interact freely with the interviewees in order to gather information on both facts and their interpretation, along with personal opinions of respondents. That is why during the interviews it was possible to discuss additional, relevant topics. The respondents were guaranteed anonymity. All of the respondents were either owners or managing board members, including sales managers and product managers. They were selected by their companies as well-informed, reliable sources of information.

The interviews were conducted in 2012. They were recorded, transcribed, divided into topic-based text segments and coded into 77 codes collected in the codebook. The codebook was the basis for analysis and interpretation of the qualitative data (Corbin, Strauss, 1990; Glaser, Strauss, 2006). Coded text segments allowed to convert some of the data into percentages and numbers in order to create the background for qualitative interpretation of the research results.

It is worth saying that the sample of companies selected for the purpose of this research consists of specific participants of the industry. They are actively engaged in research and development activities, are the suppliers of product innovations, provide their own solutions and actively operate on foreign markets. The research results drawn from such population cannot be applied to the whole population of the companies operating in the field of environmentally sound technologies. This, along with other methodological shortcomings of qualitative studies, can be seen as a research limitation. Moreover, the sample is narrowed down exclusively to the Polish companies and it might be beneficial for future studies to focus on cross-country analysis. 


\section{ANALYSIS OF FINDINGS}

\section{The origins of technology}

Development of the best technology does not guarantee business success unless it is not commercialized. The first step to introduce the solution to the market is to sell the idea to an external party or set up a company in order to develop it. Nearly $80 \%$ of interview respondents declared that the technology was developed in the existing company, of which $57.5 \%$ claimed that the company existed long before the technology was developed.

"First the company [was developed], and then the product was made. However, the product existed previously in my head. And the knowledge that was used to develop it existed before. I have to admit, that the ability to design turbines was related to the knowledge gained at the university (college and doctoral studies), in many research studies, other expertise researches and work in the laboratory (I researched more than 70 turbines in the laboratory in the University of Technology). This knowledge had been developed throughout the years, along with the product idea in my head."

[Company 38]

Every fifth company was founded to refine and implement the technology on the market, but its basic technology had been developed previously. Such scheme appeared frequently in companies that have developed innovative solutions using the employees, resources and engineering facilities of the parent company, and afterwards they established a new company dedicated to the development and implementation of this new technology. Moreover, such approach was also widely adopted by the innovators who had another job at the time of development of this technology. A small percentage of respondents at the design stage of the new solution had no intention to sell it. Most of the interviewees declared, however, that companies were established in order to fine-tune and start to sell the technology.

"First there was the idea that there is a need for such technology. It started like this... one day I said to my partner, listen, I have a very good idea to use this technology... we should start a company to be able to sell it."

[Company 24]

No matter what the origin of the enterprise is, the most important thing that speeds up the commercialization of this new technology is the existence of the company in which it is possible to conduct research, work on the new 
technology and test it. On the other hand, according to few respondents, it is a necessity to run the company while working on the new product, because the research is very expensive and public funds for this purpose are difficult to obtain by individuals, who have an idea to develop new technology.

Over $30 \%$ of the pre-existing businesses significantly changed the range of offered products or even moved to another industry during the time of their business development. In addition, 15\% of respondents declared that over the years company's interests expanded significantly. This can be seen as the proof of the fact that enterprises from the interviewed sample concentrate on searching for new business opportunities and care about the development of their technologies and products portfolios.

"At the beginning our firm was a service company focused on installing machinery and equipment. After gaining some experience in this field, we extended the range of our activities starting the commercialization of new products. This was followed by the development of trade and finally manufacturing. Now, our firm commercializes new products, manufactures them and sells them to consumers."

[Company 23]

\section{The background of technology creation}

It is very difficult to define one driving force, which was the basis for the development of all new technologies and companies from the sample. However, it is possible to identify three most important factors that, according to interviewees, had a direct impact on the start of the activities aimed at creation of new solutions that led to start a new business. According to $55 \%$ of respondents the main source of their activity was the idea created thanks to different sources of inspiration (see: Figure 2). Most of the ideas were somehow influenced by external forces, such as work opportunity with competitors, partners or customers and country's economic condition. Amongst all, in $30 \%$ of cases the idea creation processes was inspired by other market players.

"This was a negative inspiration, it means that we were looking what is out on the market and we saw that it was bad, so that we were inspired to make something different."

[Company 29]

Furthermore, the interviews' results show that $12.5 \%$ of companies were established thanks to direct cooperation with partners: in joint ventures, with

Perspectives on Innovations Management - Environmental, Social and Public Sector Innovations, Krzysztof Klincewicz, Anna Ujwary-Gil (Eds.) 
the help of a parent company or in cooperation with the higher education institution. About $10 \%$ of respondents say that the development of the technology was directly affected by a client, who declared willingness to purchase a solution that was not yet mature. This customer's need created the opportunity for faster development and testing of the technology.

"The consumer decided to buy our prototype of the product to use it and at the same time experiment with it. That's how everything began."

[Company 10]

About $15 \%$ of respondents emphasized that the economic factors played an important role in technology development. These factors included the emergence of a market gap, the desire to make money or the transformation of the Polish economy in 1990s from plan to the free market system, which has opened the way for Polish businesses to expand to other countries. Just a few companies arose from the desire of their owners to implement into practice the knowledge gained during their studies.

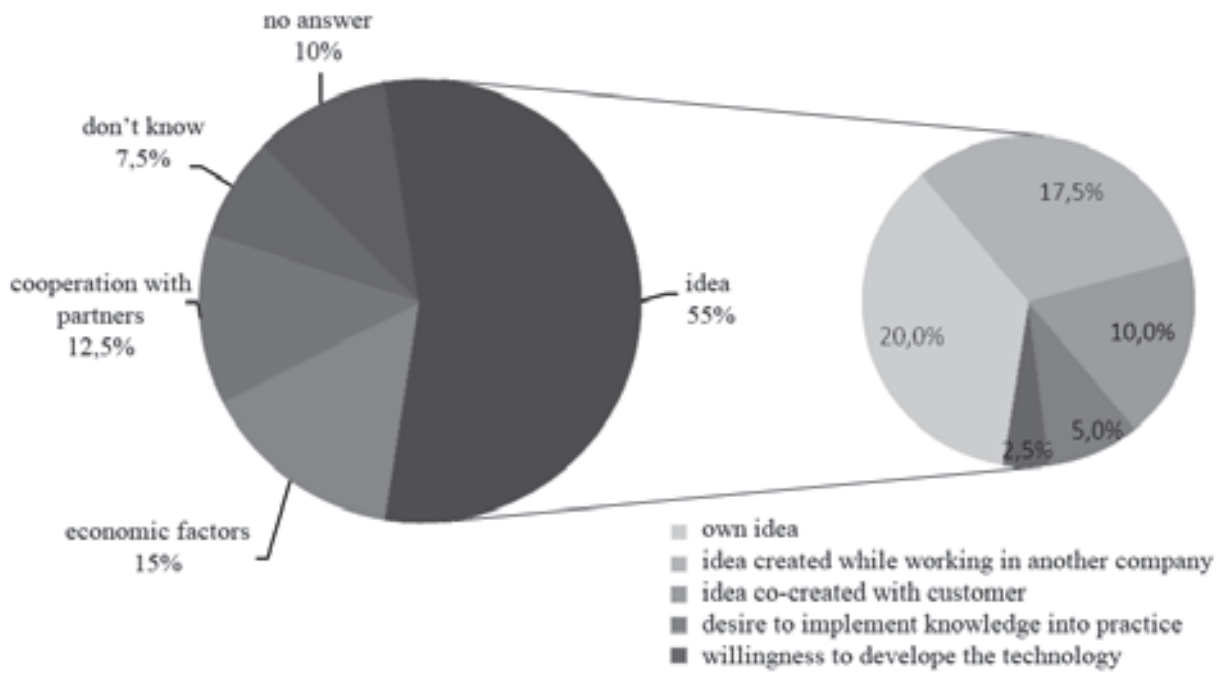

Figure 2. The background of technology creation

\section{The role of other market players}

The results of interviews conducted among the Polish enterprises revealed that entrepreneurs, while developing new technology, frequently examined and monitored the market in order to determine whether and in what areas there is a need to introduce new solutions or improvements to the 
technologies that exist so far. The engineers examined existing technologies in order to identify their functional and technical deficiencies and imperfections. According to some interviewees it is the simplest way to find week points and flaws of existing technologies. They believe that the weakness of other players in the market is a sufficient inspiration to create new solutions. Another way to study competitive products is to analyze existing patents. According to the respondents, this approach is often used to gather information on the progress of technology development and plan paths for further development of own technical solutions.

"You cannot develop a technology from start to finish by yourself, without taking into account things that have been developed by others before. (...) If somebody made the first car, then it was preceded by a rack wagon, and so on... So we always draw inspiration from similar items. However, we do not copy them, because it makes no sense. We try to identify weaknesses of available solutions and improve them while developing our own [technologies]."

[Company 24]

$60 \%$ of respondents admit that in creating new technologies they drew inspiration from similar solutions of other companies. In such cases, innovation arises from a combination of knowledge and experience of innovators and designers with the effects of the work of other market players. A significant part of respondents stated that they were inspired by unique solutions developed by companies with whom they compete, especially in terms of product functionality. $57.5 \%$ of the companies admit that they constantly track the activities of direct competitors and see it as an important factor in technology development. A large proportion of these respondents consider such behavior as a common phenomenon. A small group of interviewees claimed that the best products are made on the basis of key technologies introduced to the Polish market by foreign companies.

There are many sources of knowledge for the development of new solutions in the field of environmentally sound technologies in Poland. The majority of respondents stated that a reliable way of gathering information about the actions of other players in the market and their products are market observation and the analysis of available solutions. Becoming familiar with technological systems available on the market is considered an important element in the development of new products. Tracking the activities of competitors may also lead to the effective sharing of knowledge and experience between enterprises. Most of the respondents declared that the information obtained at trade shows and industry conferences is often useful for creating new technological solutions. According to some interviewees,

Perspectives on Innovations Management - Environmental, Social and Public Sector Innovations, Krzysztof Klincewicz, Anna Ujwary-Gil (Eds.) 
to develop effective solutions, sufficient knowledge has to be also obtained from publicly available sources, such as books, the Internet, trade magazines and technical studies. The smallest percentage of respondents believe that in order to gather the information necessary for new product development it is indispensable to cooperate with competition, also on the international level. It also happens that entrepreneurs use business intelligence agencies to obtain information that is necessary to improve or create their own technology. But this is not a common practice among the Polish companies that have been interviewed. Nevertheless, majority of the companies from the sample perceive other market players as competitors, not potential cooperators.

When asked about the purpose of developing own equivalent of the existing solutions, the companies indicated most frequently a desire to improve its functionality or introduce modern technology approaches. A few of the interviewees have been inspired by the ideas of other market players sought to fill the technological gap in the domestic market.

Developing the technology is not the only way to introduce to the domestic market solutions that are similar to those which successfully operate in other countries. The same effect can be achieved by using the technology of another company, by licensing or purchasing property rights related to the technology. Despite the fact that the companies have been aware of these possibilities, only a few have decided to follow this strategy. Regardless of whether cooperation with other market actors was present or not, according to some interviewees the main barrier that ultimately affect the failure of such cooperation regards financial issues.

Inspiration is not always associated with direct copying of complete solutions. Only $5 \%$ of the companies from the sample admit that their developed technology was not original and innovative (see: Figure 3). There has been only one case in the researched sample of companies of copying and implementing entire solutions developed by related entities operating in the industry. In such a situation one part of the technology was implemented in the same way as in the competing enterprise. In a few cases, the technologies that have been developed by the surveyed companies after their implementation turned out to be known before, but at the time of the creation, inventors were not aware of this.

$30 \%$ of the companies from the sample declare that they have not built their product ideas on the achievements of competitors, or other supply side market players. Among them, the majority admit that they were the innovation pioneers who created the market which did not previously exist and there were no similar solutions. In other words, according to the respondents, there was no competition in the industry when the new idea emerged. 
"In fact, we had nothing to refer to or gain inspiration from. We did not know what would be the feature of this [new] material. Solutions were ours, original."

[Company 22]

YES, unique world-wide

YES, suique in Poland

technology NOT, its application YES

YES, but only some elements were unique

YES, but there were similar solutions

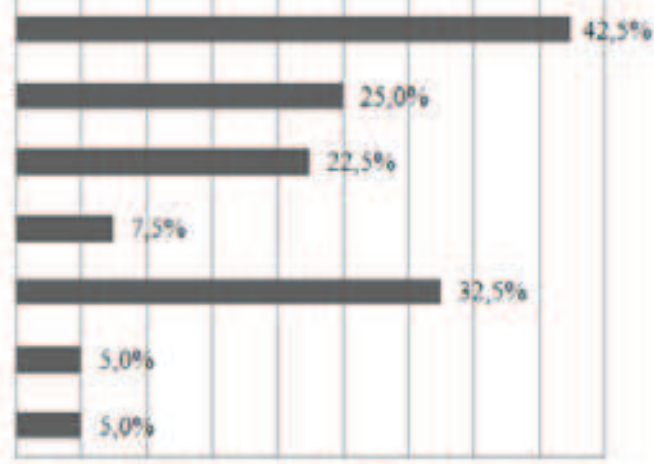

no answer

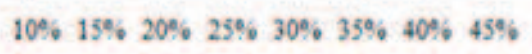

Figure 3. Responses to the question: „Was the technology unique in the moment of its development?"

\section{Customers as inventors}

As discussed in the literature review above, customers and users can be very important sources of improvements for existing technologies. $65 \%$ of respondents admitted that clients often come up with an idea for a new product or technology. It happens that potential users ask for a machine that has not been previously offered, and then a company is trying to meet their demand. Such a situation takes place more often when products are usually customized.

The experience of companies from the sample shows that acquisition of information from customers has been done in many different ways. Such information is usually gathered during conversations with clients concerning their needs and expectations, as well as possibilities to satisfy such needs by the new technology. Some respondents declared that their contact with customers was regulated in special agreements' clauses, which obliged users to provide information about technology performance. Surveys conducted among clients have been another important channel of information flow. In such surveys customers have been able to specify what additional features could better provide them excellent functionality of technology. Sometimes, it happens that the customers report problems encountered during the use of 
technology. In such a situation, according to a large group of the interviewees, the company, together with customer, seeks the best way to provide the best solution for the problem.

"We talk to the customers, [ask them] what they would like and what is their "dream" machine and what are the features that they would like the machine to have, to improve, to change. We also listen to these suggestions and on this basis we introduce more modern approaches in the new models of our products."

\section{[Company 10]}

Typically cooperation with customers turns out to be fruitful, but it does not always give expected results. Attempts to reach a compromise with the user are sometimes long and tedious. For these main reasons, $25 \%$ of the companies from the sample do not seek feedback on the efficiency of their technology. What is more, some respondents reported that the adjustments of the offered solutions to customer needs are too expensive and do not satisfy them fully, so it becomes not profitable for the company to do such adjustments. Interviewees presenting this point of view argue that the best way to develop effective and efficient technology is to rely on the knowledge and experience of designers and employees of the company.

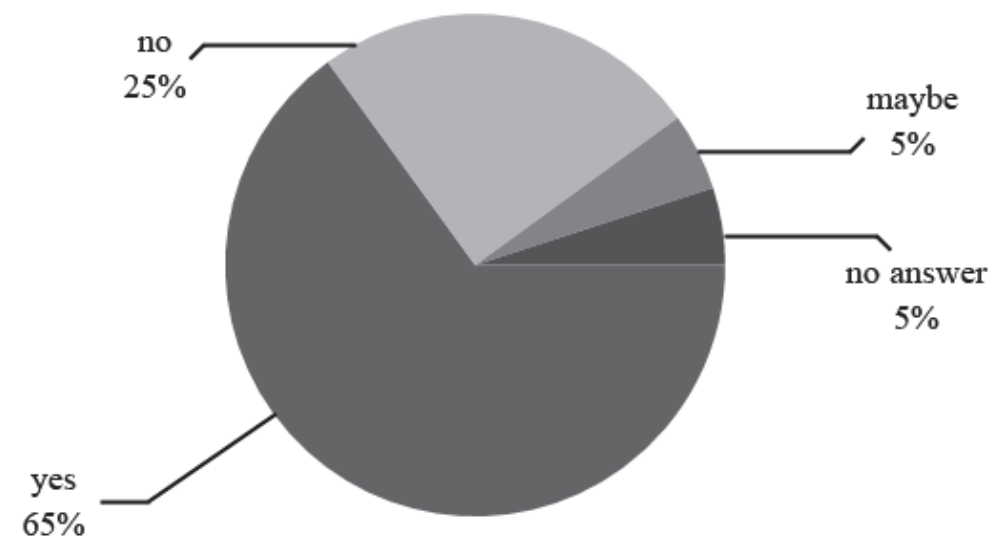

Figure 4. Responses to the question: "Have customers ever helped the company to develop its technology?" 

Technologies

\section{DISCUSSION}

As emphasized in the literature, the role of customers and competitors can be seen as important in designing new products by other market players. The literature on innovation and technology management provides a theoretical framework dedicated to the analysis of the development of innovative solutions by companies-suppliers of environmentally sound technologies.

The article has investigated the process of developing environmental technologies in a group of Polish enterprises. Results of the study show that Polish companies-suppliers of environmentally sound technologies are willing to gain inspiration from both demand and supply side market players. In case of supply side of the market, in most cases inspiration was not aimed at copying the existing successful ideas. The competitors are perceived as a source of inspiration for further development of technological solutions, which confirms the findings discussed in the theoretical part of this paper (Ansoff and Stewart, 1967; Von Hippel, 1987; Porter, 2006; Drucker, 1992). Classifying the final technologies established by the companies from the sample, it should be noted that only $5 \%$ of companies can be categorized in the framework of Ansoff and Stewart (1967) as "me-too". More than 40\% offered unique products, which can be seen as novelties on the global market and can be placed in the category "first to the market". Majority of the researched companies can be places right after the leader, in the category "follow the leader", since the technologies developed by these companies were product-equivalent solutions previously introduced by the pioneers. Nevertheless, most technologies were not available previously on the local market.

It has been demonstrated that competition can also stimulate firms to identify and fulfill customers' undiscovered and unmet needs and develop new solutions to satisfy them (Federal Trade Commission, 2003). Thus, a second crucial factor in the process of new ideas creation appears, which is the demand side element, i.e. clients. Many respondents agreed that the information gained from the market was used to develop better solutions in terms of functionality. Although companies concentrate on having a relationship with customers, these relations have not been established by the Polish companies researched here in order to treat users as co-creators of product improvements or novelties. This role of customers has been identified in the literature (Prahalad and Ramaswamy, 2004, pp. 214-215), but when it comes to the interviewed Polish firms, it was not the case. The cause of such inconsistency of the findings with the conclusions drawn from the literature may be related to the fact that the market for environmentally sound technologies in Poland is relatively young, and there are not many customers who adopt new solutions. What is more, since the adoption of such

Perspectives on Innovations Management - Environmental, Social and Public Sector Innovations, Krzysztof Klincewicz, Anna Ujwary-Gil (Eds.) 
technologies is not common, companies focus their innovation development on the predictions of needs and wants of future customers and market observation. A major part of the respondents to this interview has declared that because of the fact that the solutions they have introduced were not known previously, creating a market for them took some time. These factors might have been an obstacle in having active dialogs with users. According to the classification of company-customer interactions proposed by Prahalad and Ramaswamy, Polish companies-suppliers of environmental technologies should be classified in the category named "lifetime bonds with buyers".

\section{CONCLUSION}

From the implications of the research it can be concluded that the behavior of competitors and customers is an important factor that drives innovativeness of companies-suppliers of environmentally sound technologies. Different theoretical approaches have been used to examine the role of competitors in the development of companies' innovative products (Ansoff and Stewart, 1967; Von Hippel, 1987; Porter, 2006; Drucker, 1992). In order to identify and evaluate the impact of customers on new solution creation, Prahalad's and Ramaswamy's classification has been recalled.

The contribution of this research is two-fold. First, using in-depth interviews, it examined the innovation behaviors of the Polish companiessuppliers of environmentally sound technologies and, second, it presented the evidence of the role of competitors and consumers in the innovation processes. Evidence from Poland goes in line with theoretical findings, showing that inspiration while developing new solutions cannot be immediately associated with imitation. This paper reveals specific features in innovation behavior of the analyzed Polish companies when it comes to the role of customers as a source of innovation. The case of Polish companies in environmentally sound technology sector does not confirm user-driven innovation approach in new solutions' creation. Although companies see the need to track their customers, they are not willing to focus on having close relationships with them and fully respond to their needs. The interviews show that users have not been used as co-creators of product improvements or development of novelties, they play only an indirect role in innovation processes.

It should be, however, pointed out that the evidence of this research cannot be applied to the whole population of companies. In-depth interviews' participants were the suppliers of own, advanced environmentally sound technologies in Poland, while among other enterprises from the sector there 
are also distributors of technologies or manufacturers of less advanced solutions.

The next step in the study of this complex phenomenon could be a multiple case study research on the basis of which it will be possible to discover the reasons for such behavior of companies.

\section{References}

Ansoff, I.H. \& Stewart, J.M. (1967). Strategies for a Technology-based Business. Harvard Business Review, 45(6), 71-83.

Anthony, S.D., Eyring, M. \& Gibson, L. (2010). Mapping Your Innovation Strategy. In: Harvard Business Review on Business Model Innovation (pp. 121-145). Boston: Harvard Business School Publishing Corporation.

Azzone, G. \& Noci, G. (1996). Measuring the environmental performance of new products: an integrated approach. International Journal of Production Research, 34(11), 3055-3078.

Bansal, P. \& Roth, K. (2000). Why Companies Go Green: A Model of Ecological Responsiveness. Academy of Management Journal, 43(4), 717-736.

Białoń, L. (Ed.). (2010). Zarzq̨dzanie działalnościq innowacyjnq. Warszawa: Placet.

Bower, J.L. \& Christensen, C.M. (2010). Disruptive Technologies: Catching the Wave. In: Harvard Business Review on Business Model Innovation (pp. 19-45). Boston: Harvard Business School Publishing Corporation.

Carrillo-Hermosilla, J., Del Río, P. \& Könnölä, T. (2009). Eco-innovation. When sustainability and competitiveness shake hands. New York: Palgrave Macmillan.

Cleff, T. \& Rennings, K. (1999). Determinants of environmental product and process innovation. European Environment, 9, 191-201.

Drucker, P.F. (1992). Innowacja i przedsiębiorczość. Praktyka i zasady. Warszawa: PWE.

Ebinger, C. \& Avasarala, G. (2009). Transferring Environmentally Sound Technologies In An Intellectual Property-friendly Framework. Washington: Brookings.

Enos, J.L. (2013). Petroleum Progress and Profits: A History of Process Innovation. Whitefish: Literary Licensing.

Federal Trade Commission (2003). To Promote Innovation: The Proper Balance of Competition and Patent Law and Policy. Retrieved from http://www. ftc.gov/os/2003/10/innovationrpt.pdf.

Foray, D. (2006). The Economics of Knowledge. Cambridge, London: The MIT Press.

Franke, N. \& Shah, S. (2003). How communities support innovative activities an exploration of assistance and sharing among end-users. Research Policy, 32(1), 157-178.

Perspectives on Innovations Management - Environmental, Social and Public Sector Innovations, Krzysztof Klincewicz, Anna Ujwary-Gil (Eds.) 
Freeman, C. (1968). Chemical process plant: innovation and the world market. National Institute Economic Review, 45, 29-57.

Hienerth, C., Von Hippel, E. \& Baldwin, C.Y. (2006). How user innovations become commercial products: A theoretical investigation and case study. Research Policy, 35, 1291-1313.

Homburg, Ch., Grozdanovic, M. \& Klarmann, M. (2007). Responsiveness to Customers and Competitors: The Role of Affective and Cognitive Organizational Systems. Journal of Marketing, 71(3), 18-38.

International Environmental Technology Centre(2003). Environmentally Sound Technologies for Sustainable Development. United Nations Environment Programme, Division of Technology, Industry and Economics.

Jaffe, A.B., Newell, R.G. \& Stavins, R.N. (2004). Technology Policy for Energy and the Environment. In: A.B. Jaffe, J. Lerner, S. Stern (Eds.), Innovation Policy and the Economy 4 (pp. 35-68). Cambridge, London: The MIT Press.

Janasz, W. \& Kozioł, K. (2007). Determinanty działalności innowacyjnej przedsiębiorstw. Warszawa: PWE.

Janasz, W. \& Leśkiewicz, I. (1995). Identyfikacja i realizacja procesów innowacyjnych w przedsiębiorstwie. Szczecin: Uniwersytet Szczeciński.

Johnson, M.W., Christensen, C.M. \& Kagermann, H. (2010). Reinventing Your Business Model. In: Harvard Business Review on Business Model Innovation (pp. 47-70). Boston: Harvard Business School Publishing Corporation.

Juma, C. (1994). Promoting International Transfer of Environmentally Sound Technologies: The Case for National Incentive Schemes. In: H. O. Bergesen, G. Parmann (Eds.), Green Globe Yearbook of International Co-operation on Environment and Development (pp. 137-148). Oxford: Oxford University Press.

Luken, R. \& Van Rompaey, F. (2008). Drivers for and barriers to environmentally sound technology adoption by manufacturing plants in nine developing countries. Journal of Cleaner Production, 16(1), 67-77.

Luthje, C., Herstatt, C. \& Von Hippel, E. (2005). User-innovators and "local" information: The case of mountain biking. Research Policy, 34, 951-965.

Penc, J. (1999). Innowacje i zmiany w firmie. Transformacja $i$ sterowanie rozwojem przedsiębiorstwa. Warszawa: Placet.

Perez Pugatch, M. (2011). The Role of Intellectual Property Rights in the Transfer of Environmentally Sound Technologies. Geneva: Global Challenges Report, WIPO.

Porter, M.E. (2006). Przewaga konkurencyjna. Osiqganie i utrzymywanie lepszych warunków. Gliwice: Wydawnictwo HELION.

Prahalad, C.K. \& Krishnan, M.S. (2010). Nowa Era Innowacji. Warszawa: PWN.

Prahalad, C.K. \& Ramaswamy, V. (2004). The future of competition. Cocreating unique value with customers. Boston: Harvard Business School Press. 
Rigby, D. \& Bilodeau, B. (2013). Management Tools \& Trends 2013. Bain \& Company. Retrieved from http://bain.com/Images/BAIN_BRIEF_ Management_Tools_\%26_Trends_2013.pdf.

Riggs, W. \& Von Hippel, E. (1994). Incentives to innovate and the sources of innovation: the case of scientific instruments. Research Policy, 23(4), 459-469.

Schumpeter, J.A. (1939). Business Cycles. New York, London: McGraw Hill. Schumpeter, J.A. (1960). Teoria rozwoju gospodarczego. Warszawa: PWN.

Skea, J. (1995). Environmental technology. In: H. Folmer, H. L. Gabel, H. Opschoor (Eds.), Principles of Environmental and Resource Economics. A Guide for Students and Decision-Makers (pp. 389-412). Aldershot, Brookfield: Edward Elgar.

Sosnowska, A. (2000). Zarzqdzanie nowym produktem. Warszawa: Oficyna Wydawnicza Szkoły Głównej Handlowej.

Taylor, M.R., Rubin, E.S. \& Hounshell, D.A. (2005). Control of SO2 emissions from power plants: A case of induced technological innovation in the U.S. Technological Forecasting \& Social Change, 72, 697-718.

Tébar Less, C., McMillan, S. (2005). Achieving the Successful Transfer of Environmentally Sound Technologies: Trade-Related Aspects. OECD Trade and Environment Working Paper No. 2005-02. Paris: OECD.

United Nations (1997). Glossary of Environment Statistics, Studies in Methods. New York: United Nations.

Urban, G. I. \& Von Hippel, E. (1988). Lead User Analyses for the Development of New Industrial Products. Management Science, 34(5), 569-582.

Visser, R., Jongen, M. \& Zwetsloot, G. (2008). Business-driven innovations towards more sustainable chemical product. Journal of Cleaner Production, 16(1), 85-94.

Von Hippel, E. (1987). Cooperation Between Rivals: Informal Know-How Trading. Research Policy, 16, 291-302.

Von Hippel, E. (1988). The Sources of Innovation. New York, Oxford: Oxford University Press.

Von Hippel, E. (2005). Democratizing Innovation. Cambridge: The MIT Press.

Von Hippel, E. (2007). Horizontal innovation networks - by and for users. Industrial and Corporate Change, 16(2), 293-315.

Weber, M. \& Hemmelskamp, J. (2005). Towards environmental innovation systems. Berlin - Heidelberg: Springer.

White, Ch.J., Varadarajan, P.R. \& Dacin, P.A. (2003). Market Situation Interpretation and Response: The Role of Cognitive Style, Organizational Culture, and Information Use. Journal of Marketing, 67, 63-79.

Zook, Ch. (2010). Finding Your Right Amount of Knowledge. In: Harvard Business Review on Business Model Innovation (pp. 147-171). Boston: Harvard Business School Press. 


\begin{abstract}
Abstrakt (in Polish)
Artykuł przedstawia dwie główne siły oddziałujq̨ce na tworzenie innowacji produktowych przez dostawców technologii nieszkodliwych dla środowiska, czyli konkurentów i klientów. Praca omawia te zjawiska na bazie rozmaitych podejść teoretycznych (Ansoff i Stewart, 1967; Von Hippel, 1987, 2005, 2007; Prahalad and Ramaswamy, 2004). Wyniki badań pokazujq, że polskie firmy - dostawcy technologii nieszkodliwych dla środowiska chętnie szukajq inspiracji zarówno po stronie popytu jak i podaży rynkowych graczy. W przypadku strony podaży, w większości sytuacji inspiracja nie miała prowadzić do kopiowania już istniejqcych idei, które odniosły sukces. Konkurenci sq postrzegani raczej jako źródło inspiracji do dalszego rozwoju rozwiqzań technologicznych. Chociaż firmy koncentrujq się na tworzeniu relacji z klientami i śledzeniu ich zachowań, relacje te nie zostały jeszcze w pełni stworzone przez polskie firmy objęte naszym badaniem, a klienci nie sq wciq̨ż traktowani jako współtwórcy udoskonaleń produktów czy nowych rozwiqzań.
\end{abstract}

Słowa kluczowe: technologie środowiskowe, klienci, konkurencja, innowacje produktowe, innowacje popytowe.

\title{
Biographical note
}

Magdalena Marczewska, doctoral candidate at the Faculty of Management, University of Warsaw. She graduated from the University of Warsaw, Faculty of Management and Warsaw School of Economics. Her research interests focus on innovation management and environmental management. She studied and carried out research at the University of Kentucky, the University of Padua and the London School of Economics and Political Science. Author and co-author of two management science books. Research grant holder in the "ETIUDA" program, funded by the National Science Center (NCN), the research agency of the Polish government. 